\title{
Effect of sorbents on the content of trace elements in maize cultivated on soil contaminated with heating oil***
}

\author{
Mirostaw Wyszkowski*(1) and Veranika Sivitskaya \\ Department of Environmental Chemistry, University of Warmia and Mazury in Olsztyn, Plac Łódzki 4, 10-727 Olsztyn, Poland
}

Received September 12, 2018; accepted April 30, 2019

\begin{abstract}
The aim of this study was to determine the effect of neutralizing substances on the content of trace elements in maize on soil contaminated by heating oil. For the treatments without neutralizing substances, the dependency between increasing doses of heating oil and the cadmium content of plants was direct, yet the range of changes was relatively small. Under the influence of increasing doses of heating oil, the cadmium and manganese contents increased up to a dose of $10 \mathrm{~g}$ of oil per $\mathrm{kg}$ of soil, lead up to $15 \mathrm{~g}$ of oil per $\mathrm{kg}$ of soil and chromium within the full range of its doses, as compared to the control treatment (without heating oil). Higher doses of heating oil resulted in a decrease in cadmium, lead and manganese contents in maize. All of the tested substances had a significant effect on the content of trace elements in maize. Calcium oxide, zeolite and bentonite had a more pronounced effect than compost and nitrogen on the content of trace elements in this plant. A favourable effect, restricting the content of most of them in the maize was only observed for cadmium and manganese, in contrast to lead and chromium.

Keywords: contamination, heating oil, neutralizing substances, maize, trace elements
\end{abstract}

\section{INTRODUCTION}

The rapid development of industry over the last few decades has caused increasing levels of environmental containation, which is most often associated with trace elements, particularly those from the group commonly known as heavy metals (Kabata-Pendias and Pendias, 2001). In addition, particular importance may be attributed to oil derivatives, contamination from this source poses major environmental problems. Oil production, as well as the transport and storage of petroleum products, has been increasing steadily, which is primarily the result of an increase in the number of motor vehicles. The production of heating oil has decreased

*Corresponding author e-mail: miroslaw.wyszkowski@uwm.edu.pl

**This work was conducted as part of the scientific project of the National Science Centre No N N305 305340 (2011-2012). in recent years (CSO, 2018). During the transport of these substances, spills into water and soil are possible as a result of tanker and pipeline failures. They are difficult to neutralize and are stable enough to become concentrated in the trophic chain (Nadim et al., 2000).

Heating oil is primarily used for heating single-family houses and small production plants. In Poland, its use for heating purposes has been systematically increasing at the expense of hard coal and lignite (CSO, 2018). Most frequently, it can penetrate into the soil during transport and storage. Due to its chemical composition, it may become a source of polycyclic aromatic hydrocarbons (PAHs) and other hydrocarbons as well as trace elements. Oil derivatives have an adverse effect on soil properties, particularly on its air-water relationships; they also disrupt its enzymatic activity (Liste and Felgentreu, 2006; Wyszkowska and Wyszkowski, 2010; Ziółkowska and Wyszkowski, 2010), reduce soil fertility (Wyszkowski and Sivitskaya, 2012) and, even in small amounts, they can restrict or inhibit the growth and development of plants (Liste and Felgentreu, 2006; Rusin et al., 2015). The natural circulation of elements in nature is then disturbed, which affects their uptake by plants. Soils which have been severely contaminated with oil derivatives, including heating oil, may be purified using ex-situ methods. In the event of less severe contamination, in-situ methods may be applied, e.g. phytoremediation methods or the application of various sorbents into the soil (Ziółkowska and Wyszkowski, 2010). A special role is served here by plants belonging to a group of hyperaccumulators which absorb contaminants from the soil and are disposed of following the harvest. Sorbents are mainly

(C) 2019 Institute of Agrophysics, Polish Academy of Sciences 
effective in the event of soil contamination with trace elements (Dushenkov and Raskin, 1999; Prasad and Freitas, 2003; Dahri et al., 2018). Bentonite, zeolite and organic substances have a positive effect on plants and they reduce their uptake of trace elements from soil (Feng at al., 2007). The application of organic and mineral substances with strong sorptive properties decreases the bioavailability of heavy metals and its toxicity to plants (Bolan at al., 2003). According to Wyszkowski and Sivitskaya (2012) bentonite has a more pronounced effect on the content of available nutrients in the soil than zeolite and compost. Zeolite only increased the content of available magnesium however, bentonite had a positive effect on the content of available phosphorus, potassium and magnesium in the soil. It was reported that the application of calcium to the soil reduced the availability of heavy metals by increasing soil $\mathrm{pH}$ (Abd El-Azeem et al., 2013; Guodong, 2009). Maize, inter alia, is one of a small group of plants which are good accumulators of trace elements (Antonkiewicz et al., 2004; Mohebbi and Harutyunyan, 2010).

With regard to the above-mentioned information, a study was carried out to determine the effect of neutralizing substances on the contents of cadmium, lead, chromium and manganese in maize (Zea mays L.) on soil contaminated with heating oil.

\section{MATERIALS AND METHODS}

The study was carried out in three replications in a planthouse of the University of Warmia and Mazury in Olsztyn (north-eastern Poland) on soil with a granulometric composition of loamy sand (fractions, in $\mathrm{mm}$ : sand $>0.05 \mathrm{~mm}$ - 79.5\%; dust 0.002-0.05 mm - $18.61 \%$; and clay $<0.002$ $\mathrm{mm}-1.89 \%$ ). It was characterized by the following properties: $\mathrm{pH}_{\mathrm{KCl}}-4.52$; hydrolytic acidity (HAC) $25.4 \mathrm{mmol}(+)$ $\mathrm{kg}^{-1}$, the total exchangeable bases (TEB) $29.1 \mathrm{mmol}(+)$ $\mathrm{kg}^{-1}$, cation exchange capacity (CEC) $54.5 \mathrm{mmol}(+) \mathrm{kg}^{-1}$, base saturation (BS) $-53.4 \%$; content of $\mathrm{C}_{\text {org. }}-11.3 \mathrm{~g} \mathrm{~kg}^{-1}$; contents of available forms of: phosphorus $-71.9 \mathrm{mg} \mathrm{kg}^{-1}$; potassium - $118.6 \mathrm{mg} \mathrm{kg}^{-1}$, and magnesium - $104.2 \mathrm{mg}$ $\mathrm{kg}^{-1}$, contents of total forms of: cadmium $-0.18 \mathrm{mg} \mathrm{kg}^{-1}$, lead - $4.95 \mathrm{mg} \mathrm{kg}^{-1}$, chromium - $2.34 \mathrm{mg} \mathrm{kg}^{-1}$ and man- ganese $-196.7 \mathrm{mg} \mathrm{kg}^{-1}$. The soil was contaminated with heating oil in the following amounts: $0,5,10,15$ and 20 $\mathrm{g} \mathrm{kg}^{-1}$ of soil. The study was conducted in six series: without the application and with the application of: nitrogen

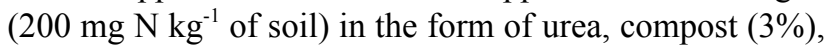
bentonite, zeolite ( $2 \%$ in relation to the weight of the soil), and $50 \%$ calcium oxide at a dose corresponding to full hydrolytic acidity $\left(10.93 \mathrm{~g} \mathrm{Ca} \mathrm{kg}^{-1}\right.$ of soil). Compost was prepared from leaves (44\%), manure (33\%) and peat (23\%) composted for six months. The chemical compositions of urea, compost, bentonite and zeolite are presented in Table 1. Other properties of these elements were previously published by Wyszkowski and Sivitskaya (2013). Fertilizer components were also applied to each pot in equal amounts (in $\left.\mathrm{mg} \mathrm{kg}^{-1}\right): \mathrm{N}-100 \mathrm{CO}\left(\mathrm{NH}_{2}\right)_{2}, \mathrm{P}-30\left(\mathrm{KH}_{2} \mathrm{PO}_{4}\right) ; \mathrm{K}-100$ $\left(\mathrm{KH}_{2} \mathrm{PO}_{4}+\mathrm{KCl}\right) ; \mathrm{Mg}-50\left(\mathrm{MgSO}_{4} 7 \mathrm{H}_{2} \mathrm{O}\right) ; \mathrm{Mn}-5\left(\mathrm{MnCl}_{2}\right.$ $\left.4 \mathrm{H}_{2} \mathrm{O}\right) ; \mathrm{Mo}-5\left(\left(\mathrm{NH}_{4}\right)_{6} \mathrm{Mo}_{7} \mathrm{O}_{24} 4 \mathrm{H}_{2} \mathrm{O}\right) ; \mathrm{B}-0.33\left(\mathrm{H}_{3} \mathrm{BO}_{3}\right)$. The soil $(9 \mathrm{~kg})$ was thoroughly mixed with the added heating oil and the above-mentioned substances and then placed into polyethylene pots. The experiment was carried out in 3 replications. The maize (Zea mays L.) of Polish variety Reduta was used as a test plant, with a density of 8 plants per pot. During the study, the moisture content of the soil was maintained at a level of $60 \%$ of the capillary water capacity. The maize was harvested during the phase of intense stem growth and samples of the above-ground parts of plants (63 days of growing) were taken for laboratory analysis.

Plant samples were dried and ground and then subjected to "wet" mineralization in nitric acid $\left(\mathrm{HNO}_{3}\right.$, analytical grade) with a concentration of $1.40 \mathrm{~g} \mathrm{~cm}^{-3}$ in HP500 Teflon vessels in a MARS 5 microwave oven (CEM Corporation, USA), according to the methodology US-EPA3051A (2007). In the mineralized samples, the cadmium, lead, chromium and manganese contents were determined using a flame atomic absorption spectroscopy method (FAAS) in an air-acetylene flame, using a SpectrAA 240FS atomic absorption spectrophotometer (VARIAN, Austria). For the analyses, Fluka standard solutions with the following reference codes; Cd 51994, Pb 16595, Cr 02733 and Mn 63534, were used. The methods of soil analysis prior to setting up the experiment were provided in a previously published

Table 1. Content of elements in substances used in the experiment

\begin{tabular}{|c|c|c|c|c|c|c|}
\hline Element & Unit & Nitrogen & Compost & Bentonite & Zeolite & Calcium oxide \\
\hline$P$ & \multirow{5}{*}{ ( $\mathrm{g} \mathrm{kg}^{-1}$ d.m.) } & & 2.32 & 0.47 & 0.11 & 0.10 \\
\hline $\mathrm{K}$ & & & 1.33 & 2.43 & 23.21 & 0.77 \\
\hline $\mathrm{Mg}$ & & & 1.47 & 5.03 & 0.31 & 2.65 \\
\hline $\mathrm{Ca}$ & & & 15.86 & 26.72 & 15.28 & 347.99 \\
\hline $\mathrm{Na}$ & & & 0.12 & 12.11 & 16.12 & 0.07 \\
\hline $\mathrm{Cd}$ & \multirow{4}{*}{ (mg kg ${ }^{-1}$ d.m.) } & 0.64 & 0.04 & 0.27 & 1.36 & 8.90 \\
\hline $\mathrm{Pb}$ & & 0.30 & 1.98 & 9.90 & 18.00 & 60.00 \\
\hline $\mathrm{Cr}$ & & 2.69 & 1.13 & 2.67 & 1.81 & 2.70 \\
\hline $\mathrm{Mn}$ & & 4.00 & 5.40 & 145.00 & 2.04 & 295.02 \\
\hline
\end{tabular}


study by Wyszkowski and Sivitskaya (2013). In order to determine the significance of the effects of the tested factors on the contents of the trace elements under study in the maize, two-factor variance analysis (ANOVA), correlation coefficients and a principal component analysis (PCA) from the Statistica package (Dell Inc., 2016) were used.

\section{RESULTS AND DISCUSSION}

The effects of increasing the doses of heating oil on the content of the tested elements in the soil were varied (Table 2). Maize accumulated cadmium in small amounts, ranging from 0.05 to $0.10 \mathrm{mg} \mathrm{kg}^{-1} \mathrm{~d} . \mathrm{m}$. In the series without additives, the dependency between increasing the doses of heating oil and the cadmium content of plants was direct $(\mathrm{R}=0.567)$, yet the range of changes was relatively small. Under the influence of increasing doses of heating oil, the manganese content increased by $64 \%$ up to a dose of $10 \mathrm{~g}$ $\mathrm{kg}^{-1}$ of soil in the maize, as compared to the control treatment (without heating oil). An increase in the lead content in maize was noted under the influence of $15 \mathrm{~g}$ of oil per $\mathrm{kg}$ of soil. Higher doses of heating oil resulted in a decrease in the manganese and chromium contents in maize. As a result of the activity of heating oil, the chromium content in the maize increased by $89 \%$ ( $20 \mathrm{~g}$ of oil $\mathrm{kg}^{-1}$ of soil, $\left.\mathrm{R}=0.954\right)$ in relation to the treatment without the addition of this oil derivative.

Maize (Zea mays L.) is a good accumulator of trace elements (Raskin et al., 1997). Maize accumulates large amounts of lead (Raskin et al., 1997; Dushenkov and Raskin, 1999; Mohebbi and Harutyunyan, 2010; Nezdoyminow and Chernysheva, 2010) and cadmium (Mohebbi and Harutyunyan, 2010; Jasiewicz et al., 2010; Nezdoyminow and Chernysheva, 2010). In a study by Rusin et al. (2015), diesel fuel, which is characterized by properties similar to those of heating oil, reduced the cadmium content and increased the accumulation of lead and manganese in the leaves of broad bean plants. The analogous effect of hydrocarbons originating from oil derivatives on the cadmium and manganese contents of the leaves of Vernonia amygdelina and Talinum triangular was also noted by Nwaichi et al. (2014). In an experiment by Sivitskaya and Wyszkowski (2013), increasing the levels of contamination in the soil with the addition of heating oil resulted in a decrease in the copper and zinc content and an increase in the accumulation of nickel in maize.

The application of oil spill mitigating substances into the soil had a significant effect on the content of the tested trace elements, most of them reduced the content of cadmium and manganese in maize, in contrast to lead and chromium (Fig. 1). For soils contaminated with heating oil, the application of compost, bentonite, zeolite and $\mathrm{CaO}$ into the soil had a favourable, limiting effect on the cadmium content of the maize. In general, the manganese content of the maize under the influence of mitigating substances significantly decreased as compared to the series without additives. The substance which most effectively restricted the uptake of manganese by maize was bentonite, which caused a decrease in its content by $68 \%$. Calcium oxide reduced the manganese content in maize by $44 \%$, compost by $22 \%$, and zeolite by $19 \%$. An exception to this trend was the addition of nitrogen, which stimulated an increase in the content of the tested element in the maize by an average of $18 \%$ in relation to the series without additives. All substances contributed to a significant increase in the $\mathrm{Pb}^{2+}$ content of the maize: compost by an average of $33 \%$, nitrogen by $35 \%$, bentonite by $63 \%, \mathrm{CaO}$ by $105 \%$ and zeolite by $123 \%$, as compared to the series without additives. As for chromium, all substances except nitrogen stimulated an increase in its content to a small extent, and the largest amounts were noted in the series with zeolite $(+17 \%)$ and $\mathrm{CaO}(+22 \%)$.

The correlation coefficients shown in Table 3 indicate highly significant correlations between cadmium and chromium, lead and manganese, and chromium and lead in the maize. The cadmium and manganese contents in the maize were negatively correlated with the $\mathrm{pH}$ value, total exchangeable bases, cation exchange capacity and base saturation, as well as the chromium content of the soil. Also, the manganese content of the maize was significantly positively correlated with the hydrolytic acidity of the soil. A positive correlation was found between the contents of chromium and lead in the maize and the $\mathrm{pH}$ and accumulation of chromium, a negative correlation with the lead content of the soil was also demonstrated.

The cumulative result of soil contamination with heating oil and neutralizing substances (nitrogen, compost, bentonite, zeolite and calcium oxide) on the contents of selected trace elements in the maize is presented in Fig. 2 using PCA analysis in the form of vector variables. The total correlation of the data set for the first group of trace elements (cadmium, chromium, and lead) was $64.71 \%$ and for the second group (manganese) it was $21.08 \%$. Having compared the length of the vectors of the analysed elements, it may be concluded that they were of a similar length, which indicates their almost comparable effect (with a slight predominance of manganese) as a share of variability. The angle of the position of the vectors between the elements indicates a highly significant positive correlation between the vectors of chromium and lead and a considerably weaker one between cadmium and manganese. A small negative correlation was found between cadmium and chromium as well as lead. The correlations between cadmium and chromium as well as cadmium and lead were smaller than those between chromium and lead and between cadmium and manganese. The dispersion of the cases of PCA analysis indicates that it was the application of calcium oxide, bentonite and zeolite that had the largest effect on the contents of the analysed trace elements in the soil (Fig. 3). 
Table 2. Content of trace elements in the above-ground parts of maize (Zea mays L.) (mg kg ${ }^{-1} \mathrm{~d} . \mathrm{m}$.)

\begin{tabular}{|c|c|c|c|c|c|c|c|}
\hline \multirow{2}{*}{$\begin{array}{c}\text { Dose } \\
\text { of heating oil } \\
\left(\mathrm{g} \mathrm{kg}^{-1} \text { of soil }\right)\end{array}$} & \multicolumn{7}{|c|}{ Substance added and its neutralizing effect in the presence of heating oil } \\
\hline & $\begin{array}{l}\text { Without } \\
\text { additions }\end{array}$ & Nitrogen & Compost & Bentonite & Zeolite & $\mathrm{CaO}$ & Average \\
\hline \multicolumn{8}{|c|}{ Cadmium } \\
\hline 0 & 0.07 & 0.09 & 0.09 & 0.06 & 0.07 & 0.07 & 0.08 \\
\hline 5 & 0.08 & 0.10 & 0.08 & 0.07 & 0.06 & 0.06 & 0.08 \\
\hline 10 & 0.09 & 0.09 & 0.06 & 0.06 & 0.06 & 0.06 & 0.07 \\
\hline 15 & 0.09 & 0.10 & 0.07 & 0.06 & 0.06 & 0.06 & 0.07 \\
\hline 20 & 0.08 & 0.09 & 0.07 & 0.05 & 0.05 & 0.05 & 0.07 \\
\hline Average & 0.08 & 0.09 & 0.07 & 0.06 & 0.06 & 0.06 & 0.07 \\
\hline $\mathrm{R}$ & $0.567^{*}$ & 0.316 & $-0.693 *$ & $-0.671 * *$ & $-0.965 * *$ & $-0.894 * *$ & $-0.806^{* *}$ \\
\hline LSD & \multicolumn{7}{|c|}{$\mathrm{a}-0.004^{* *}, \mathrm{~b}-0.004^{* *}, \mathrm{a} \times \mathrm{b}-0.009^{* *}$} \\
\hline \multicolumn{8}{|c|}{ Lead } \\
\hline 0 & 0.50 & 0.65 & 0.62 & 0.96 & 1.09 & 1.09 & 0.82 \\
\hline 5 & 0.44 & 0.93 & 0.74 & 0.86 & 1.29 & 1.30 & 0.93 \\
\hline 10 & 0.72 & 0.79 & 0.66 & 0.96 & 1.40 & 1.23 & 0.96 \\
\hline 15 & 0.77 & 0.80 & 0.81 & 0.98 & 1.37 & 1.26 & 1.00 \\
\hline 20 & 0.45 & 0.72 & 0.97 & 1.13 & 1.31 & 1.13 & 0.95 \\
\hline Average & 0.58 & 0.78 & 0.76 & 0.98 & 1.29 & 1.20 & 0.93 \\
\hline $\mathrm{R}$ & 0.232 & 0.015 & $0.880^{* *}$ & $0.749 * *$ & $0.678^{*}$ & 0.071 & $0.786^{* *}$ \\
\hline LSD & \multicolumn{7}{|c|}{$\mathrm{a}-$ n.s., $\mathrm{b}-0.14^{* *}, \mathrm{a} \times \mathrm{b}-\mathrm{n} . \mathrm{s}$} \\
\hline \multicolumn{8}{|c|}{ Chromium } \\
\hline 0 & 0.70 & 1.11 & 1.15 & 1.20 & 1.12 & 1.57 & 1.14 \\
\hline 5 & 0.89 & 1.04 & 1.18 & 1.26 & 1.30 & 1.39 & 1.18 \\
\hline 10 & 1.19 & 1.15 & 1.24 & 1.29 & 1.36 & 1.36 & 1.26 \\
\hline 15 & 1.18 & 1.08 & 1.27 & 1.28 & 1.34 & 1.47 & 1.27 \\
\hline 20 & 1.32 & 1.18 & 1.29 & 1.25 & 1.41 & 1.37 & 1.30 \\
\hline Average & 1.06 & 1.11 & 1.23 & 1.26 & 1.31 & 1.43 & 1.23 \\
\hline $\mathrm{R}$ & $0.954 * *$ & 0.500 & $0.979 * *$ & 0.566 & $0.869 * *$ & -0.566 & $0.961 * *$ \\
\hline LSD & \multicolumn{7}{|c|}{$\mathrm{a}-0.08^{* *}, \mathrm{~b}-0.09^{* *}, \mathrm{a} \times \mathrm{b}-0.19^{* *}$} \\
\hline \multicolumn{8}{|c|}{ Manganese } \\
\hline 0 & 357.8 & 584.5 & 361.7 & 57.3 & 269.2 & 149.7 & 296.7 \\
\hline 5 & 409.3 & 375.8 & 349.7 & 114.0 & 366.3 & 225.0 & 306.7 \\
\hline 10 & 587.3 & 552.5 & 276.2 & 167.5 & 488.5 & 313.8 & 397.6 \\
\hline 15 & 499.2 & 659.2 & 414.3 & 137.5 & 446.8 & 329.2 & 414.4 \\
\hline 20 & 446.7 & 711.2 & 473.7 & 195.3 & 271.0 & 209.7 & 384.6 \\
\hline Average & 460.1 & 576.6 & 375.1 & 134.3 & 368.4 & 245.5 & 360.0 \\
\hline $\mathrm{R}$ & 0.481 & $0.661^{*}$ & $0.617 *$ & $0.896 * *$ & 0.133 & 0.472 & $0.824 * *$ \\
\hline LSD & \multicolumn{7}{|c|}{$\mathrm{a}-10.8^{* *}, \mathrm{~b}-11.8^{* *}, \mathrm{a} \times \mathrm{b}-26.4^{* *}$} \\
\hline
\end{tabular}

LSD for: $\mathrm{a}$ - heating oil dose, $\mathrm{b}$ - neutralizing substance, $\mathrm{a} \times \mathrm{b}$ - interaction; significant for: ${ }^{*} \mathrm{p} \leq 0.05, * * \mathrm{p} \leq 0.01$, n.s. - not-significant, $\mathrm{R}$ - correlation coefficient. 

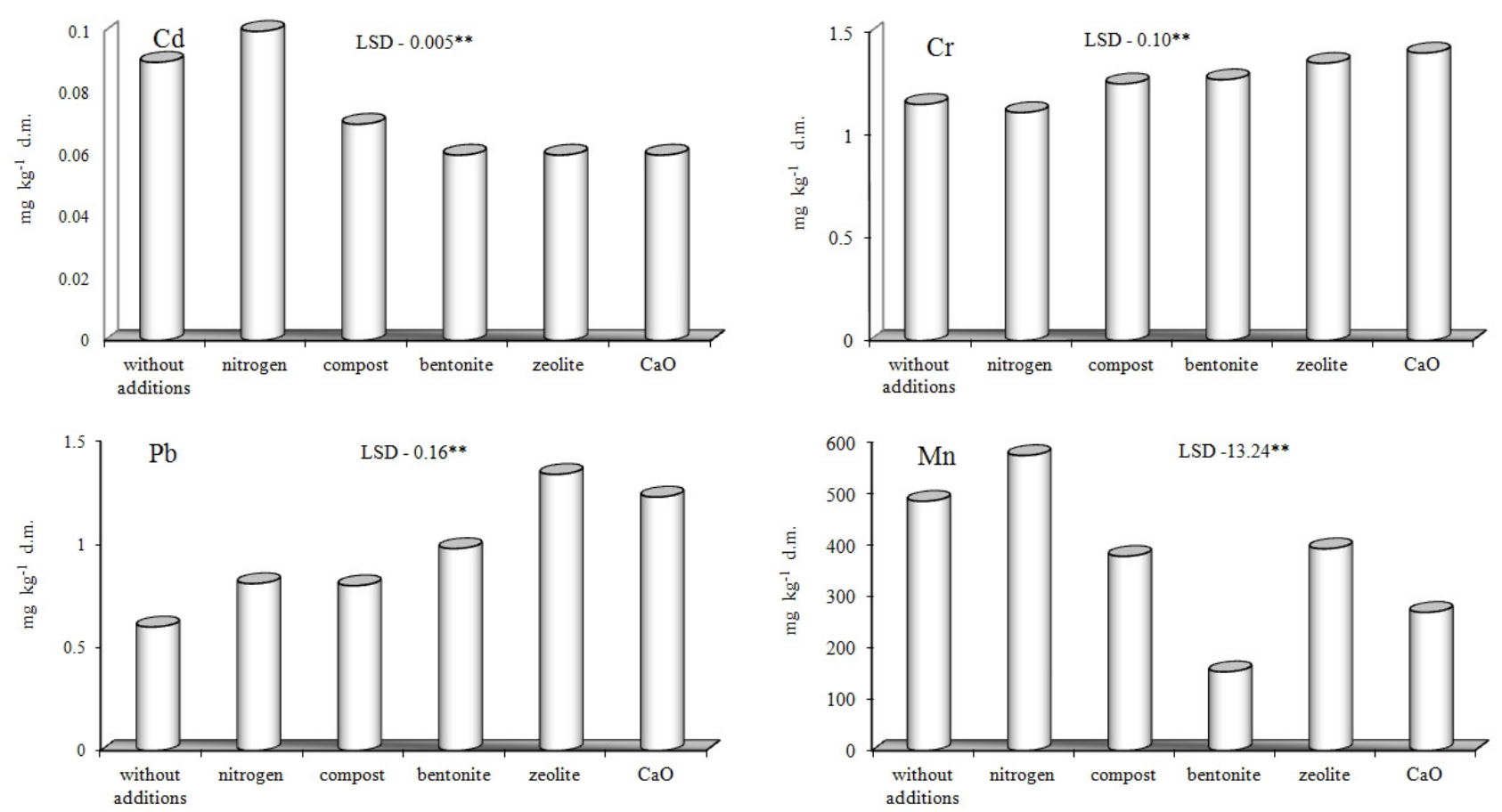

Fig. 1. Content of trace elements in the above-ground parts of maize (Zea mays L.), average from series contaminated with 5-20 g heating oil per $\mathrm{kg}$ of soil differences significant for: $* \mathrm{p}=0.05, * * \mathrm{p}=0.01$.

Table 3. Correlation coefficients $(\mathrm{R})$ between the content of trace elements in the above-ground parts of maize (Zea mays L.) and the content of trace elements and some other properties of the soil

\begin{tabular}{|c|c|c|c|c|}
\hline \multirow{2}{*}{ Factor } & \multicolumn{4}{|c|}{ Content of trace elements in maize (Zea mays L.) } \\
\hline & $\mathrm{Cd}$ & $\mathrm{Cr}$ & $\mathrm{Pb}$ & $\mathrm{Mn}$ \\
\hline \multicolumn{5}{|c|}{ Maize (Zea mays L.) } \\
\hline $\mathrm{Cd}$ & & $-0.640 * *$ & $-0.511 * *$ & $0.680 * *$ \\
\hline $\mathrm{Cr}$ & $-0.640 * *$ & & $0.673 * *$ & -0.328 \\
\hline $\mathrm{Pb}$ & $-0.511 * *$ & $0.673 * *$ & & -0.313 \\
\hline $\mathrm{Mn}$ & $0.680 * *$ & -0.328 & -0.313 & \\
\hline \multicolumn{5}{|c|}{ Soil after the harvesting of maize (Zea mays L.) } \\
\hline $\mathrm{pH}_{\mathrm{KCl}}$ & $-0.659 * *$ & $0.593 * *$ & $0.621 * *$ & $-0.724 * *$ \\
\hline $\mathrm{HAC}$ & 0.258 & 0.008 & -0.249 & $0.569 * *$ \\
\hline TEB & $-0.423 *$ & 0.212 & 0.230 & $-0.622 * *$ \\
\hline CEC & $-0.420 *$ & 0.235 & 0.190 & $-0.538 * *$ \\
\hline BS & -0.349 & 0.134 & 0.258 & $-0.646^{* *}$ \\
\hline $\mathrm{Cd}$ & 0.071 & -0.244 & 0.035 & 0.015 \\
\hline $\mathrm{Cr}$ & $-0.766^{* *}$ & $0.796^{* *}$ & $0.664 * *$ & $-0.499 * *$ \\
\hline $\mathrm{Pb}$ & 0.207 & $-0.477 * *$ & $-0.536^{* *}$ & -0.093 \\
\hline $\mathrm{Mn}$ & 0.126 & -0.066 & -0.069 & -0.032 \\
\hline
\end{tabular}

$\mathrm{pH}_{\mathrm{KCl}}-\mathrm{pH}$ in $1 \mathrm{M} \mathrm{KCl}, \mathrm{HAC}$ - hydrolytic acidity, TEB - total exchangeable bases, CEC - cation exchange capacity, BS - base saturation. Significant at $* \mathrm{p} \leq 0.05, * * \mathrm{p} \leq 0.01 ; \mathrm{R}-$ correlation coefficient.
The addition of mineral fertilizers may either reduce the number of available trace elements, or contribute to their increase, if they are also sources of these elements. The effects of nitrogen fertilizers are determined by the dose, the type of fertilizer and the time of application. Fertilizers containing reduced forms of nitrogen (urea) increase the number of available forms of trace elements, and decrease the $\mathrm{pH}$ of the soil, this was confirmed by the author's own study. In a study by Sady and Smolen (2004), increasing the doses of nitrogen resulted in an increased accumulation of cadmium, zinc and nickel, and had no effect on the lead and copper content of carrot. In the author's own study, nitrogen had a stimulating effect on the accumulation of lead, manganese and cadmium and reduced the accumulation of chromium in maize. All additives applied to the soil contributed to an increase in the lead content of the maize.

The organic matter of the soil, and the matter that is introduced along with the organic fertilizers, contributes to a reduction in the availability of trace elements to plants and the obtained yield contains considerably fewer trace elements (Sady and Smoleń, 2004). According to Goldberg (2002), the application of an organic substance contributes to a reduction in the uptake of trace elements by plants. Jasiewicz et al. (2010) indicate that an increase in the lead content of maize in the series with an addition of inland water sediment, and a reduction in the accumulation of cadmium and chromium, which is partially confirmed by the results of the author's own study. Nezdoyminov and Chernysheva (2010) observed that organic fertilization 
(with sewage sludge) contributed to a slight increase in the accumulation of trace elements in the plants. In the series with compost from the author's own study, an increase in the lead and chromium contents were noted as well as a decrease in the accumulation of manganese and cadmium in maize.

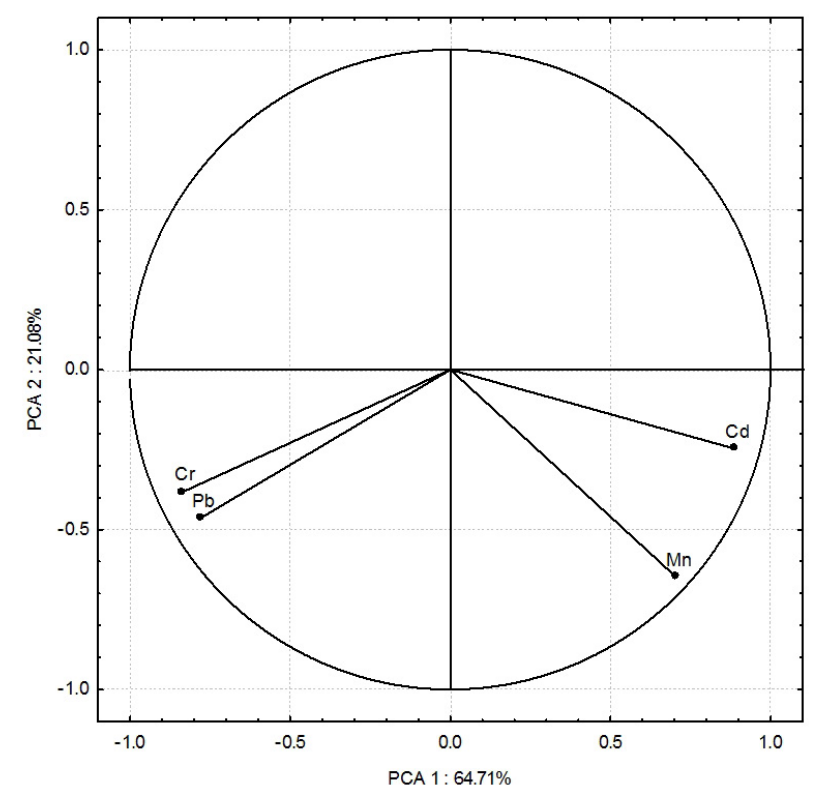

Fig. 2. Content of trace elements in the above-ground parts of maize (Zea mays L.), average from series contaminated with 5-20 g heating oil per kg of soil. Differences significant for: $* \mathrm{p}=0.05, * * \mathrm{p}=0.01$.
Bedelean et al. (2009) also confirmed the effectiveness of bentonite in the sorption of cadmium, lead, and chromium from wastewater. Bentonite decreased the availability of cadmium and lead for wheat, and increased the yields of this plant in an experiment by Usman et al. (2006). Bentonite proved to be more effective in immobilizing trace elements than zeolite. Changes in the soil environment, e.g. an increase in the amount of organic matter, or changes to the $\mathrm{pH}$ of the soil, can increase the mobility of trace elements and lead to a reduction in the effectiveness of silty minerals in their immobilization. According to Usman et al. (2005), the presence of $\mathrm{Ca}^{2+}$ and $\mathrm{Al}^{3+}$ ions decreased the effectiveness of the sorption of trace elements by minerals. In the authors' own study, bentonite contributed to an increase in the accumulation of chromium and lead and had a restricting effect on the content of manganese and cadmium in maize.

Rehakova et al. (2004), and Prasad and Freitas (2003), confirmed the effective action of zeolites, which prevent the uptake of trace elements by plants. Sady and Smolen (2004) observed a decrease in the cadmium content of carrot roots under the influence of diatomite. According to Ulmanu et al. (2006), the application of zeolite decreased the uptake of $\mathrm{Pb}^{2+}, \mathrm{Cd}^{2+}$ and $\mathrm{Mn}^{2+}$ ions by maize from contaminated soil. The lead and cadmium contents in the maize decreased by 25 and $35 \%$, respectively when a dose of $2.5 \%$ zeolite was added to the soil. Castaldi et al. (2005) found that zeolite can increase the heavy metal fraction in the soil, but it reduces the uptake of heavy metals by plants. Sivitskaya and Wyszkowski (2013) found that zeolite reduced the content of some trace elements in maize. In

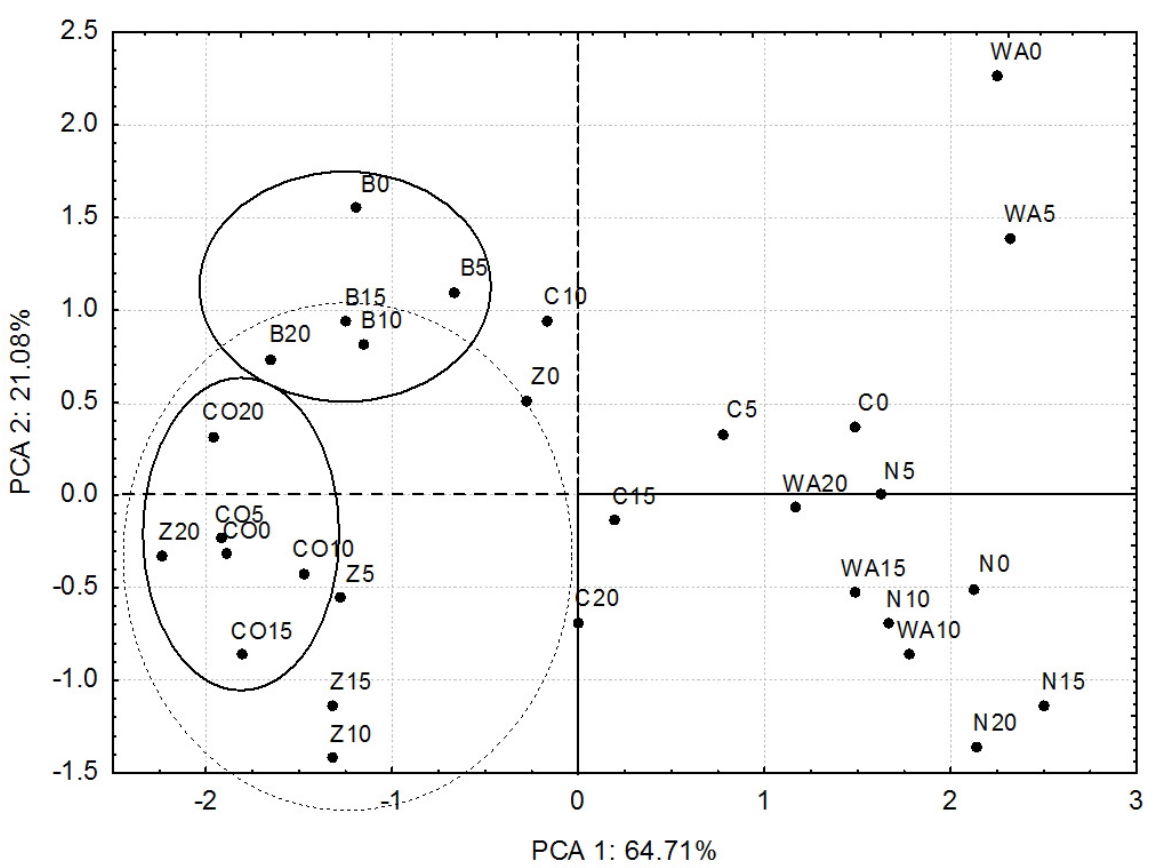

Fig. 3. Effect of neutralizing substances on the content of trace elements in the above-ground parts of maize (Zea mays L.) illustrated with the PCA method. Key: points show samples with trace elements (WA - without additions, $\mathrm{N}$ - nitrogen, $\mathrm{C}$ - compost, B - bentonite, $\mathrm{Z}$ - zeolite, $\mathrm{CO}$ - calcium oxide; $0,5,10,15,20-0 \mathrm{~g}, 5 \mathrm{~g}, 10 \mathrm{~g}, 15 \mathrm{~g}$, and $20 \mathrm{~g}$ heating oil $\mathrm{kg}^{-1}$ of soil, respectively). 
their experiment, zeolite exhibited a stimulating effect on the accumulation of lead and chromium in the maize and it also had a restricting effect on the contents of manganese and cadmium in the maize.

The $\mathrm{pH}$ value is regarded as the main factor which has an effect on the form of the occurrence of trace elements and on their availability to plants. Sady and Smolen (2004) confirmed the favourable effect of liming, which reduced the content of cadmium and lead in cabbage, lettuce and sugar beet. However, the mobility of heavy metals can occasionally increase in an alkaline soil. This phenomenon is caused by the formation of mobile metallorganic complexes. These "metal + organic substance" combinations are easily absorbed by plants. Therefore, on soils rich in organic substances, a liming treatment may contribute to an increase in the amount of heavy metals available to plants. The uptake of trace elements disturbs the uptake of macronutrients by plants and results in disturbances to the growth and development of plants. Many metal cations, including $\mathrm{Cd}^{2+}$ and $\mathrm{Pb}^{2+}$, are available to plants in a soil solution with a low $\mathrm{pH}$ value, i.e. below 5.5 (Prasad and Freitas, 2003). As is the case with lead, the high content of an element in the soil does not necessarily contribute to an increase in its content in plants due to poor solubility. Plants absorb trace elements poorly since they occur in the soil in the form of compounds with low solubility, therefore the concentration of $\mathrm{Pb}$ in plants did not exceed $50 \mathrm{mg} \mathrm{kg}^{-1}$, even in the best hyperaccumulator of lead, i.e. Indian mustard (200 mg $\mathrm{kg}^{-1}$ ). The optimum availability of lead occurs in a soil with a $\mathrm{pH}$ value of 5.5-7.5, while higher and lower $\mathrm{pH}$ values increase or decrease the solubility of this element, respectively. Lead is accumulated in the cell walls of plant roots in the form of lead carbonates. A reduction in the $\mathrm{pH}$ value from 5.5 to 3.5 stimulates the movement of lead from the roots to the stems (Blaylock et al., 1997). In the author's own study, in a series with calcium oxide, an increase was noted in the contents of lead and chromium in the maize, as well as a decrease in manganese and cadmium levels.

\section{CONCLUSIONS}

1. In treatments without neutralizing substances, contamination with heating oil resulted in an increase in the content of all trace elements in the maize: for cadmium and manganese, only up to a dose of $10 \mathrm{~g}$ of oil per $\mathrm{kg}$ of soil and for lead, up to $15 \mathrm{~g}$ of oil per $\mathrm{kg}$ of soil. Higher doses of heating oil resulted in a decrease in cadmium, lead and manganese contents in maize. It had the most pronounced effect on the increase in the chromium content of the maize.

2. All tested substances had a significant effect on the content of trace elements in the maize. The favourable and restricting effect of most of them was only observed for cadmium and manganese. The application of compost, bentonite, zeolite and $\mathrm{CaO}$ into the soil resulted in a decrease in both the cadmium and manganese contents in the maize.
3. All tested substances contributed to the accumulation of lead and chromium in the maize compared to the series without additives. Calcium oxide, zeolite and bentonite had a more pronounced effect than compost and nitrogen on the contents of trace elements.

Conflict of interest: The Authors do not declare conflict of interest.

\section{REFERENCES}

Adb El-Azeem S.A.M., Ahmad M., Usman A.R.A., Kim K.R., Oh S.E., Lee S.S., and Ok Y.S., 2013. Changes of biochemical properties and heavy metal bioavailability in soil treated with natural liming materials. Environ. Earth Sci., 70(7), 3411-3420. https://doi.org/10.1007/s12665-013-2410-3

Antonkiewicz J., Jasiewicz Cz., and Ryant P., 2004. The use of heavy metal accumulating plants for detoxication of chemically polluted soils. Acta Univ. Agric. Silvic. Mendel. Brun., 52(1), 113-120.

https://doi.org/10.11118/actaun200452010113

Bedelean H., Măicăneanu A., Burcă S., and Stanca M., 2009. Removal of heavy metal ions from wastewaters using natural clays. Clay Miner., 44(4), 487-495.

https://doi.org/10.1180/claymin.2009.044.4.487

Blaylock M.J., Salt D.E., Dushenkov S., Zakarova O., Gussman C., Kapulnik Y., Ensley B.D., and Raskin I., 1997. Enhanced accumulation of $\mathrm{Pb}$ in Indian mustard by soil-applied chelating agents. Environ. Sci. Technol., 31, 860-865. https://doi.org/10.1021/es960552a

Bolan N., Adriano D., Mani S., and Khan A., 2003. Adsorption, complexation, and phytoavailability of copper as influenced by organic manure. Environ. Toxicol. Chem., 22(2), 450-456. https://doi.org/10.1002/etc.5620220228

Castaldi P., Santona L., and Melis P., 2005. Heavy metal immobilization by chemical amendments in a polluted soil and influence on white lupin growth. Chemosphere, 60(3), 365371. https://doi.org/10.1016/j.chemosphere.2004.11.098

CSO, 2018. Statistical Yearbook of the Republic of Poland 2018. Central Statistical Office, Warszawa, 913.

Dahri I., Tagar A., Adamowski J., Leghari N., Shah A., and Soomro S., 2018. Influence of straw incorporation-to-planting interval on soil physical properties and maize performance. Int. Agrophys., 32(4), 341-347. https://doi.org/10.1515/intag-2017-0027

Dell Inc., 2016. Dell Statistica (data analysis software system), version 13. software.dell.com.

Feng N., Dagan R., and Bitton G., 2007. Toxicological approach for assessing the heavy metal binding capacity of soils. Soil Sediment Contam., 16(5), 451-458. https://doi.org/10.1080/15320380701490226

Dushenkov V. and Raskin I., 1999. Phytoremediation: a new green revolution in ecology. Chem. Life, 11-12, 48-49.

Goldberg S., 2002. Competitive Adsorption of arsenate and arsenite on oxides and clay minerals. Soil Sci. Soc. Am. J., 66, 413-421. https://doi.org/10.2136/sssaj2002.4130

Guodong Y., 2009. Copper, zinc, and nickel in soil solution 
affected by biosolids amendment and soil management. Aust. J. Soil Res., 47(3), 305-310. https://doi.org/10.1071/ sr08171

Jasiewicz Cz., Baran A., and Tarnawski M., 2010. Effect of bottom sediment on content, bioaccumulation and translocation of heavy metals in maize biomass. J. Elem., 15(2), 281-290. https://doi.org/10.5601/jelem.2010.15.2.281-290

Kabata-Pendias A. and Pendias H., 2001. Trace Elements in Soils and Plants. CRC Press, Boca Raton, FL, USA. https://doi.org/10.1017/s0014479711000743

Liste H. and Felgentreu D., 2006. Crop growth, culturable bacteria and degradation of petrol hydrocarbons (PHCs) in a long-term contaminated field soil. Appl. Soil Ecol., 31(12), 43-52. https://doi.org/10.1016/j.apsoil.2005.04.006

Mohebbi A. and Harutyunyan S., 2010. The absorption of heavy metals by plants from contaminated soils in the province of Khuzestan (Iran). Izv. Agron. Agroekol., 3, 50-53.

Nadim F., Hoag G.E., LiuSh., Carley R.J., and Zack P., 2000. Detection and remediation of soil and aquifer systems contaminated with petroleum products: an overview. J. Petrol. Sci. Eng., 26, 169-178. https://doi.org/10.1016/s0920-4105(00)00031-0

Nezdoyminov V.I. and Chernysheva O.A., 2010. Migration of heavy metal ions from urban sewage sludge using as fertilizer. Visnik Donbas. Nats. Akadem. Budiv. Arkhit. Probl. Ark. Mistobud., 2(82), 150-157.

Nwaichi E.O., Wegwu M.O., and Nwosu U.L., 2014. Distribution of selected carcinogenic hydrocarbon and heavy metals in an oil-polluted agriculture zone. Environ. Monit. Assess., 186(12), 8697-8706. https://doi.org/10.1007/s10661-014-4037-6

Prasad M.N.V. and Freitas H.M., 2003. Metal hyperaccumulation in plants - biodiversity prospecting for phytoremediation technology. Electr. J. Biotech., 6(3), 285-320.

Raskin I., Smith R.D., and Salt D., 1997. Phytoremediation of metals: using plants to remove pollutants from the environment. Curr. Opin. Biotechnol., 8(2), 221-226. https://doi. org/10.1016/s0958-1669(97)80106-1

Rehakova M., Cuvanova S., Dzivak M., Rimar J., and Gavalova Z., 2004. Agricultural and agrochemical uses of natural zeolite of the clinoptilolite type. Curr. Opin. Solid State Mater. Sci., 8, 397-404. https://doi.org/10.1016/j.cossms.2005.04.004

Rusin M., Gospodarek J., and Nadgórska-Socha A., 2015. The effect of petroleum-derived substances on the growth and chemical composition of Vicia faba L. Polish J. Environ. Stud., 24(5), 2157-2166. https://doi.org/10.15244/pjoes/41378
Sady W. and Smoleń S., 2004. Influence of soil and fertilizing factors on the accumulation of heavy metals in plants (in Polish). In: The effectiveness of applying fertilizers in horticultural crops. Wyd. AR Poznań, Poland.

Sivitskaya V. and Wyszkowski M., 2013. Effect of heating oil and neutralizing substances on the content of some trace elements in maize (Zea mays L.). Ecol. Chem. Eng. A, 20(3),323-331.https://doi.org/10.5601/jelem.2013.18.4.317

Ulmanu M., Anger I., Gament E., Olanescu G., Predescu C., and Sonaciu M., 2006. Effect of a romanian zeolite on heavy metals transfer from polluted soil to corn, mustard and oat. U. Politeh. Buch., Ser. B, 68(3), 67-78.

US-EPA Method 3051A, 2007. Microwave assisted acid digestion of sediment, sludges, soils, and oils. United States Environmental Protection Agency, 30. https:/www.epa. gov/sites/production/files/2015-12/documents/3051a.pdf

Usman A.R.A., Kuzyakov Y., Lorenz K., and Stahr K., 2006. Remediation of a soil contaminated with heavy metals by immobilizing compounds. J. Plant Nutr. Soil Sci., 169, 205212. https://doi.org/10.1002/jpln.200421685

Usman A.R.A., Kuzyakov Y., and Stahr K., 2005. Effect of immobilizing substances and salinity on heavy metals availability to wheat grown on sewage sludge-contaminated soil. Soil Sedim. Contam., 14, 329-344.

https://doi.org/10.1080/15320380590954051

Wyszkowska J. and Wyszkowski M., 2006. Role of compost, bentonite and lime in recovering the biochemical equilibrium of diesel oil contaminated soil. Plant Soil Environ., 52(11), 505-514. https://doi.org/10.17221/3541-pse

Wyszkowska J. and Wyszkowski M., 2010. Activity of dehydrogenases, urease and phosphatases in soil polluted with petrol. J. Toxicol. Environ. Health, A, 73(17), 1202-1210. https://doi.org/10.1080/15287394.2010.492004

Wyszkowski M. and Sivitskaya V., 2012. Changes in the content of organic carbon and available forms of macronutrients in soil under the influence of soil contamination with fuel oil and application of different substances. J. Elem., 17(1), 139-148. https://doi.org/10.5601/jelem.2012.17.1.12

Wyszkowski M. and Sivitskaya V., 2013. Effect of heating oil and neutralizing substances on the content of some trace elements in soil. Fresenius Environ. Bull., 22(4), 973-978.

Ziółkowska A. and Wyszkowski M., 2010. Toxicity of petroleum substances to microorganisms and plants. Ecol. Chem. Eng., S, 17(1), 73-82. 